\title{
GCU
}

Glasgow Caledonian

University

University for the Common Good

\section{Using major events to increase social connections: the case of the Glasgow 2014 Host City Volunteer programme}

Rogerson, Robert J.; Nicholson, Rafaelle; Reid, Fiona; Sly, Bridget

Published in:

Journal of Policy Research in Tourism, Leisure and Events

DOI:

10.1080/19407963.2019.1696351

Publication date:

2021

Document Version

Author accepted manuscript

Link to publication in ResearchOnline

Citation for published version (Harvard):

Rogerson, RJ, Nicholson, R, Reid, F \& Sly, B 2021, 'Using major events to increase social connections: the case of the Glasgow 2014 Host City Volunteer programme', Journal of Policy Research in Tourism, Leisure and Events , vol. 13, no. 1, pp. 94-106. https://doi.org/10.1080/19407963.2019.1696351

\section{General rights}

Copyright and moral rights for the publications made accessible in the public portal are retained by the authors and/or other copyright owners and it is a condition of accessing publications that users recognise and abide by the legal requirements associated with these rights.

Take down policy

If you believe that this document breaches copyright please view our takedown policy at https://edshare.gcu.ac.uk/id/eprint/5179 for details

of how to contact us. 


\section{Using major events to increase social connections: the case of the Glasgow 2014 Host City Volunteer programme}

\section{Introduction}

There is growing interest by policy makers and event managers in using major events strategically for social, economic and environmental purposes (Chalip, 2014). Event legacies have become a common feature of the rhetoric associated with the bidding and hosting of major events, helping to justify significant investments made to be host and garnering public support for the event (Koutrou et al, 2016; Preuss, 2015; Thomson et al, 2013). Beyond these more direct impacts, events are also increasingly being viewed as opportunities to leverage additional, less direct impacts (Chalip, 2017) including the generation of social benefits. Such leveraging seeks to utilise the experiences and liminoid feelings engendered by events to create social outcomes through strategic and managed approaches. The underlying theory of change is that major sporting events can help to inspire social change, with the experience breaking 'down social barriers, thereby enabling behaviours and social interaction that might otherwise be unlikely or impossible during everyday life' (Chalip, 2014, 5).

One element of such leveraging that has attracted attention is connected with the use and management of event volunteers, the often large 'army' of helpers who support the delivery of the event. In recent years, opportunities to utilise the event time roles to engender future volunteering has become a part of event legacy (Doherty, 2009;

Koutrou et al, 2016). In turn this has encouraged research into how such event volunteering can be managed and delivered in ways to maximise future volunteering whilst also ensuring successful delivery of the event (eg Allen et al, 2014; Auld et al, 2009; Blackman et al, 2017; Farrell et al, 2009). 
In contrast to this extensive research on volunteering legacies, considerably less attention has been directed towards examining whether volunteering at a one-off sporting event might leverage other social outcomes, including improvements in social connectedness. Further, there has been an almost complete absence of studies considering how the management of event volunteering can influence such social leveraging. Within the context of such absences, and with specific reference to one event volunteer programme connected with the 2014 Commonwealth Games in Glasgow which sought to enhance social connectedness, this article considers some of the practical and policy implications of using major sporting event volunteering to enhance social connections.

To do this, the article is divided into five sections. After a brief review of social connectedness and major sporting events, the discussion is situated within the context of the dedicated Host City Volunteer (HCV) programme, developed for the 2014 Glasgow event as a direct policy response to the failure of traditional event volunteering approaches to engage with those least socially connected. The second section details the origins and characteristics of the HCV initiative examining how its development sought to address concerns amongst civic policy makers that anticipated legacies were at risk without such directed interventions. Third, drawing on empirical research conducted with the HCV volunteers, the paper identifies the immediate and longer-term impacts of their roles on their social connectedness, concluding that despite the initiative providing strong potential for improved social connections, in the longer term these have not been realised. The final two sections discuss the implications arising from this conclusion, first in terms of future event volunteer management approaches seeking to use one off events to foster social connectedness, and then finally the wider public policy rhetoric of anticipating event volunteering to create social legacies and the ways in which legacy 
is planned.

\section{Volunteering, social connectedness and major sporting events}

There is growing evidence globally that volunteerism encourages the development of social relationships, networks and social connectedness (Blackshaw \& Long, 2005; Gilster 2012; Kawachi \& Berkman, 2001). Social connectedness is a key aspect of social capital focused specifically on the quality and quantity of social relationships in networks. It forms a key element of social capital, following Cohen and Prusak (2001, 4), as 'social capital consists of the stock of active connections among people: the trust, mutual understanding, and shared values and behaviors that bind the members of human networks and communities and make cooperative action possible'. It is generally defined as 'the level of an individual's integration into his or her social milieu and the fullness of the resulting associative networks' (Timpone, 1998: 59), building on Lee \& Robbins' (1995) original 'social connectedness' scale. More recently, it has been measured through indicators reflecting both the number of gatherings, networks and relationships (Bowling, 1997) and subjective measures of social contacts, reduced isolation and feelings of loneliness (De Jong \& van Tilburg, 2006; Hughes et al, 2004; Russell et al, 1980).

In the context of sport, studies of long term volunteers indicate that their involvement is positively correlated with high levels of social connectedness (Auld, 2008; Cuskelly, 2008; Doherty \& Misener, 2008; Hoye et al., 2015; Kay \& Bradbury, 2009; Tonts, 2005; Zakus et al, 2009). In the UK, for example, public policy discourse since the early 2000s amongst successive British governments has widely argued that promoting sport volunteerism generates social capital and connectedness (Holmes, 2009; Morgan, 2013) whilst sports bodies argue that sport volunteering has a propensity 
to create new connections between volunteers, people and local communities (Sport England 2017). Despite such adoption in policy rhetoric, scepticism remains over whether this exceeds the ability of certain sporting activities and voluntary organisation to increase social capital and social connectedness (Coalter, 2007; Hoye \& Nicholson, 2012) as well as difficulties in assessing social connections (Dwyer et al, 2000; Preuss, 2015; Wallstam et al, 2018). This has encouraged empirical testing of these links, with studies such as Darcy et al $(2014 b)$ and Welty Peachey et al $(2013,33)$ finding that volunteers increase their 'active citizenship and engagement with society, which helped facilitate norms of reciprocity and giving back to the community'. Others are more cautious, with Hoye et al (2015: 18) suggesting that although involvement in sport was associated with increased social connectedness for individuals, 'the measurable effect was small and can be regarded as much as a caution against some of the more extravagant claims made for sport's contribution to social "goods" than as a confirmation of them'.

In contrast to the studies of the impact of long-term and regular volunteering and sport, there has been limited research into social connectedness associated with one-off, prestigious sporting events, such as the Olympics, World Cups, or Commonwealth Games (Misener \& Mason, 2006; Kay \& Bradbury, 2009). One exception is Nichols and Ralston's (2012) research with the Manchester Event Volunteers Programme, set up after the 2002 Commonwealth Games in Manchester, highlighting that the volunteers in the city felt that they had gained friends and contacts from their experiences. However, only $30 \%$ of their respondents had been volunteers associated with the sporting event, with others recruited subsequently. More recently, studies of the 'Clyde-sider' volunteers at the 2014 Commonwealth Games showed that they had developed friendships and gained in confidence as a result of their experience (Woodall et al, 
2016), but also concluded that those who had simply applied to be a Clyde-sider and not actually been successful in the process also reported an increase in connectedness.

Beyond such specific examples, Misener \& Mason (2006) argue that it is possible to create successful 'community networks' as a result of event volunteering if certain conditions are in place as part of event management. These include

consideration of social connections at all stages of the event from planning to legacy, collaborative action to empower local communities to become agents of change, and open communication and mutual learning throughout strategic activities related to events to minimise power brokering.

\section{The HCV programme}

In this paper, we focus on a specific initiative, the Host City Volunteer programme (HCV), set up to leverage social connections and inclusion through management of volunteering at the 2014 Commonwealth Games. It formed part of the wider legacy and policy ambitions of the city government (Glasgow City Council, 2009) set within its Legacy Framework, to use the event to encourage people in Glasgow to participate in volunteering, including the official event volunteer programme. The City Council sought strategically to use the unique opportunity of the Commonwealth Games to target individuals that would not normally consider volunteering, including those facing barriers to participation in volunteering (eg disabled people, asylum seekers, people with caring responsibilities) and to use the event to increase the number of people registered as volunteers in the city. To this end, the Council as one of the event partners and legacy planners sought to maximise the number of Glasgow residents registering to be part of the main event volunteer programme - the Clyde-siders - and set internal targets associated with recruitment from the above harder to reach groups. In this 
respect, the Glasgow 2014 ambitions were similar to the aims of previous mega sports events held in the UK, where both Manchester 2002 Commonwealth Games (Downward et al, 2005; Nichols and Ralston, 2012) and the London 2012 Olympics (Nichols, 2012; Nichols and Ralston, 2012) aimed to use their volunteering programmes to promote social inclusion.

By focusing on leveraging social benefits wider than volunteering, the $\mathrm{HCV}$ initiative contrasts with most previous event volunteer programmes associated with major sporting events. These - such as the Games Makers and Ambassadors at the London 2012 Olympics, and 'Team No-side' at the 2019 Rugby World Cup in Toyko have anticipated that a volunteering legacy will be their lasting outcome (Harris, 2012; Nichols \& Ralston, 2015). The HCV initiative was also distinctive in that it was created much later in the event management cycle, sought to target more specific groups of people to be volunteers, and was managed by locally based civic organisations outside of the main event organising committee.

The initiative was a direct response to the perception by two key event stakeholders, Glasgow Life and Glasgow City, to emerging evidence ahead of the event that the Clyde-sider programme would fail to meet their legacy ambitions to be inclusive. The recruitment of the Clyde-siders, organised and managed by the local event Organising Committee (OC) Glasgow 2014, had attracted considerable public interest, with more than 51,000 people applying for the 15,000 roles (later reduced to $12,500)$; a position that meant the $\mathrm{OC}$ had to conduct extensive interviewing to select volunteers. With pressure to ensure delivery of the 'best Games ever' and to fulfil their event related obligations, the OC's selection process resulted in the majority of those chosen to be Clyde-siders had previous volunteering experience, with skills and 
interests that matched the event-time role requirements.

Despite shared legacy ambitions set by the local civic partners to use the Clydesider volunteer programme to be more inclusive than previous majority sporting events (Glasgow City Council, 2009), the profile of the applicants and the subsequently selection process led to an event volunteer cohort which failed to include generally under-represented and disadvantaged communities in volunteering (SMG, 2016). In particular, applicants from within Glasgow formed not only a lower proportion than expected (13.8\% compared with Glasgow City Council target of $22 \%$ ), and it failed to reach three key groups. Older people over 60 years of age formed only 9\% (against a target of $20 \%$ ), people with disability $4.2 \%$ (compared with target of between $5 \%$ and $12 \%$ ), and people in the most disadvantaged communities forming less than $5 \%$. This under-representation reinforced a key conclusion, identified by the Glasgow Household Survey in autumn 2012, that whilst $88 \%$ of Glaswegians believed the Commonwealth Games would be positive for the city only $52 \%$ thought it would impact directly and positively on them and their families (Glasgow Household Survey, 2012). Such difficulties in the recruitment of a more diverse group of volunteers was not unique to Glasgow, having been associated with previous major sporting events (eg Darcy et al, 2014a; Nichols \& Ralston, 2012; Zhuang \& Girginov, 2012).

Faced with this disconnect, consultations by Glasgow Life with local and national agencies suggested that a range of barriers had been constructed (often unintentionally) which discouraged participation from under-represented and disadvantaged groups. Some of these barriers related to the recruitment process, including: the encouragement to apply online; setting a minimum age of 16 at application; requiring specific documentation for security screening, and indicating a 
minimum time commitment to roles. Others were created by applicant perceptions, including those on welfare benefits worried that by volunteering their benefit entitlement might be affected, as well as more general issues of self-confidence and self-efficacy to fulfil the roles. Taken together, the evidence suggested a high risk of failing to meet declared national and local (city) legacy goals to increase volunteering and community engagement set out in the Legacy Framework.

Against this backdrop, the HCV programme was created to harness the anticipation, excitement and momentum of the Glasgow 2014 Commonwealth Games in a different way to that adopted by the OC. Management of the HCV programme was coordinated by Glasgow Life and involved delivery partners in the city, and was discrete from the Clyde-sider programme. It was a three year programme running from December 2013 through to December 2016, with its central focus on event time volunteering in July and August 2014, but including pre-event training and post-event celebrations and support.

Its core event time activity paralleled aspects of the volunteering structures of 2012 London Olympics where local Ambassador volunteers, who like the HCVs were located in the areas surrounding venues augmented the official volunteers, termed Games Makers (Nichols, 2012). The HCV initiative sought to recruit up to 1500 volunteers from target groups under-represented in the Clyde-sider programme, to train and support them to have event time 'wayfinding' roles, and to create learning material to assist the volunteers to know about their city (Glasgow Life, 2013b). After the event, the programme also would develop, coordinate and integrate pathways for the HCVs to volunteer for cultural and sporting events in the city (Rogerson et al, 2015; SMG, 2016). For the participants, there was an expectation that the event volunteer role would 
improve their confidence, knowledge and skills to take part in volunteering, generate an enhanced sense of pride in their city, and make them feel more socially connected to the city and their communities. It would also provide further opportunities to feel connected with, and have an active part in, delivery of the Games.

A dedicated team was set up within Glasgow Life to recruit Host City

Volunteers from across all communities in the city, primarily using existing networks to reach into communities. There was not an open public call for volunteers, and HCVs were either personally invited or encouraged by local organisation leaders to apply.

Glasgow Life staff provided training for Games time roles, whilst the organisation also provided logistical support and volunteer welfare services during the event. The volunteers were organised into teams and deployed across the city to welcome and help direct visitors and spectators to and from venues. Volunteers were supported in their roles by an orientation day in May 2014, and information packs during the event. There was flexibility in the number and duration of volunteering sessions expected of each volunteer, allowing them to select what worked within their own lives. During the Commonwealth Games, the HCVs were allocated roles within the city centre, the pathways to the sports venues, and at the main sites across the city where cultural events were being held. They were organized into small teams of 8-10 people, with a trained team leader, with duties indicated at the start of each shift, and each team having the opportunity to meet other HCVs at the management centre within the Glasgow Life headquarters.

After the Commonwealth Games, HCVs were encouraged to contribute their memories and stories to a public exhibition housed in the People's Palace museum, with the showcase material co-designed by Glasgow Museum staff and HCVs. Contact by 
email was maintained by Glasgow Life with those HCVs who gave permission to offer information about other volunteering opportunities, primarily supported by the City Council, for the year after the Games. Thereafter Glasgow Life directed HCVs to the long established Volunteer Glasgow website, offering information about volunteer development and volunteering opportunities in communities.

This targeted approached resulted in those recruited including $31 \%$ who reported that they had never volunteered before, $15 \%$ identified as disabled, 11\% were aged 65 plus and 38\% were considered "hard pressed" according to their Acorn CACI profile (Sly, 2018).

\section{Methods: Investigating social connectedness}

A fundamental element of the HCV programme was a desire to leverage the volunteering experiences of those involved to engender greater social connectedness, breaking down some of the barriers that discouraged citizens from engaging in local volunteering and equipping them to connect more within their communities. The impact of the initiative in these respects has been investigated through quantitative and qualitative approaches conducted in the immediate aftermath of the event, and three years later, by the authors.

Nine hundred and ninety-three (993) of the HCVs were invited to respond to two surveys, having given consent to Glasgow Life to take part in the research. The first survey, conducted in September 2014, sought to identify the overall experience in the role as $\mathrm{HCV}$ and their intentions in relation to future volunteering, asking each respondent to reflect on the benefits of being a HCV. The second survey, conducted in October and November 2017, asked questions relating to the HCVs' feeling of 
connection with their community. As well as indicating whether they felt more connected to their local community more than prior to the Commonwealth Games (i.e. before July 2014), each respondent was asked to assess whether they talked more to neighbours, met up with people more, and were able to influence decisions in their local community more. They also indicated their involvement and frequency of engagement with social groups and clubs in the last 12 months and 3 years ago. Recognising the importance of framing questions in an appropriate manner (Downward, et al, 2005), the majority of questions were adapted from those used in the UK General Household Survey. Two hundred and eight (208) HCVs responded to the first survey (response rate $20 \%$ ) and three hundred and thirty-three (333) HCVs responded to the second (response rate 33\%). While for privacy reasons individual respondent data could not be matched with data from the earlier $2014 \mathrm{HCV}$ study - as is suggested as the ideal by Dickson et al (2015) - the profile of respondents was generally representative of the HCV population. The quantitative data was analysed using SPSS.

A second, qualitative stage of the research brought together two different groups of HCVs. In 2014, 26 people were interviewed before, during and after the Commonwealth Games, representing a cross-section of HCVs in terms of age, ethnicity, disability and previous volunteering experience. The interviews were designed to encourage reflection of the $\mathrm{HCV}$ experience, the role and expectations, as well as some discussion on future plans. In 2017, following on from the second survey, 15 different respondents joined three focus groups, clustered by reported changes in their social connectedness and levels of volunteering. The primary aim of these groups was to identify more intangible changes that the survey may have been unable to capture, and in particular to explore more deeply the reasons for change in their social connectedness. The discussion focussed on connections with their local communities, 
with family and friends, and with the city of Glasgow. The impact of being a HCV was then explored in relation to such connectedness, and to their formal and informal volunteering roles. The focus group interviews were recorded and transcribed, then analysed thematically using NVIVO.

\section{Results and analysis}

Research conducted with the HCVs immediately after the Games suggested that their event volunteering had the potential to assist them to build social connectedness, and pointed to achieving Glasgow Life's desire to generate a legacy through maximising opportunities for local people to feel connected with and play an active part in delivery of the Games (Glasgow Life, 2013a). The vast majority of the volunteers found the experience very positive (89\%), likely to inspire them to become more active citizens, and left with a feeling of being more connected to the city. Amongst the respondents there was a strong feeling of being proud of being a $\mathrm{HCV}(95 \%)$, satisfaction with their role $(89 \%)$ and a willingness to be involved in future events if asked $(88 \%)$. For this majority of respondents, the descriptors frequently used to capture their enthusiasm were 'unforgettable', 'fantastic' and 'enjoyable'. This survey also revealed that the majority felt more confident (76\%) and more valued (73\%) as a result of being a $\mathrm{HCV}$ (Rogerson et al, 2015).

The most frequently mentioned benefit from the role was that of 'meeting people' identified by $78 \%$ of respondents, with 'feeling part of Glasgow', 'helping people', the 'atmosphere of the city', and 'being part of the Games' also considered strengths of the role. The 2014 interviews reinforced the perceived positives from being a HCV, captured by one of the disabled HCVs: 'I definitively developed during the CWG, that experience itself, it just gave me so much confidence, more understanding in 
myself.... I never understood that before that so it definitively encourage me to do more.'

Despite this event legacy, the principal conclusion from the follow on 2017 survey conducted 3 years after the event was that the majority of the HCVs experienced little change in their social connectedness since the Commonwealth Games. Most felt the same levels of social connection to their communities and continued to have the same levels of involvement with organisations and clubs. Across the indicators of social connectedness relating to how they engaged with neighbours or connected with their local community (Table 1), between $49 \%$ and $76 \%$ of HCVs suggested there was no change in their behaviour.

(Table 1 here)

There was a similar pattern in relation to involvement with social groups and clubs. As Table 2 a illustrates, $73 \%$ continued to have the same involvement, or for $22 \%$ lack involvement. For those actively involved, $28 \%$ increased their frequency, and $21 \%$ declined, but most continued with the same frequency of involvement since being a HCV (Table 2b). For them their role as HCV, whilst memorable and positive, had not resulted in significant change in their own behaviour and engagement with others through formal organisations. In this respect, the leveraging anticipated through the role was not achieved.

(Table 2 here)

Nevertheless, a sizeable minority (22\%) signaled they were more connected. In asking each respondent to elaborate on why they felt this many pointed to an increase in confidence and open-mindedness, better knowledge and information to help them 
connect socially, and most connected this to their HCV volunteering roles. Typical comments were 'I am a more open and confident person', 'I can talk to people more as I got confidence doing the Games', and 'I think I am more connected now than 3 years ago is that I am not afraid to open more and trust the people who are my friends'. Other noted 'I have been inspired to do other things that I would not have done before', 'volunteering has made me more aware of other people' and '(I am) more aware of neighbours and what is going on'.

For this cohort, their time as a HCV had brought positives, often expressed in terms of changing outlooks on life, which in turn enabled them to engage in more social activities. Typical were these three comments emerging from the focus group discussions:

'It made a huge difference. It gave me confidence. I have joined some local groups and I have been looking after my health and trying to maintain my fitness. I also enjoyed so much about my city and meeting lots of different people. It was a wonderful and enjoyable learning experience for me and I would love to be involved again in any capacity'.

'It has given me a different outlook. I had just been widowed and was retired from work. It helped me to get out and meet new people. I loved the feeling it gave me, giving visitors to our beautiful city help and information. I also made many friends whom I have met in other volunteering roles since.'

It was a very positive experience, and I was very glad to have done it and been part of the positive welcome to our city. It gave me more interest in 'having a go' and trying new things. I have since been volunteering at a children's community group ...' 
While the HCV experiences were influential, increased levels of social connectedness also reflected changes in their personal circumstances not directly related to the event roles. 'More opportunities have arisen in my area for activities I am interested in', 'I have moved to Glasgow and my neighbourhood feels much more friendly than where I lived 3 years ago' and 'I have more time now and go to more local groups' typifies explanations offered. Changes in personal circumstances were also key factors amongst the $8 \%$ who indicated a reduction in social connections, including their own health, those of the family, or new jobs and changes in employment circumstances, and a movement away from Glasgow.

\section{Discussions and Implications}

For most sporting mega-events, the focus of a legacy directly attributable to the event itself (i.e. not leveraged through other initiatives aligned with the event) has been placed on developing post-event volunteering. Echoing Kodama et al (2013), the HCV initiative indicates that it is possible to use event strategically with appropriate management to recruit and encourage volunteers at major events to foster their social connectedness. Such leveraging is, however, likely to be limited where volunteers are already well connected into their communities, including undertaking activities in social and organisational settings. It is much stronger where the event volunteering provides a first and first-hand opportunity to engage with others, to build self-confidence and to be supported by others, including other volunteers. It remains to be researched whether any event volunteer programme needs to have a mixed profile of well and poorly connected participants to achieve this, or whether a more targeted approach to recruit primarily those least connected will be effective. Despite their ambition to achieve such a profile, the HCV initiative had a more mixed profile. 
Most success in enhancing social connectedness is likely amongst smaller, more targeted groups recruited from those areas of society that traditionally are least likely to have social capital and to be involved in event volunteering roles. Those HCVs from the economically deprived areas and those with disabilities were the main beneficiaries. In this respect, the experience of the HCVs and the significant impact on a small number of people mirrors past research on wider social inclusion projects (Long et al, 2002; Collins, 2003) making it more difficult to draw out general conclusions on what is most effective. While a one-off event may not be able to transform the lives of all those involved, directing human and financial resources to the recruitment, training and support of such key groups can have greatest longer-term impact, enabling them to gain the confidence, knowledge and experience required to increase their social networks and connections.

The HCV programme also illustrates that adopting particular event management and planning tools may increase the likelihood of leveraging social outcomes. Such tools acknowledge that the event volunteering role is a new experience for the participant, requiring opportunities to learn about being socially connected, and being agile enough to respond to the consequences of such learning. Thus, building the HCV programme around organisational structures that encourage collaborative roles, such as team working with trained team leaders, supported and encouraged social connections amongst the volunteers. The flexibility to move HCVs between roles, rather than allocation to particular tasks for the duration of the event, assisted the HCVs to build on emerging strengths and interests, and to view the experience as one of continuous learning.

For future research, and perhaps the most significant aspect of the $\mathrm{HCV}$ 
programme, underlines Byers et al's (2019) call for greater attention to be paid to the fluid nature of legacy and legacy planning. The need for a volunteering programme of type, its construction and funding, and its impact were determined by the presence of pre-event evaluations, and a willingness by event partners to respond to evidence of failure. By viewing legacies as being constructed around planned, pre-determined objectives there is limited scope to investigate the unexpected, unvalued and unplanned legacies (Byers et al, 2019). This absence is reinforced by the operationalisation of legacy primarily as 'outcomes' to be measured following the event (eg Bauman et al's (2015) analysis of whether the 2000 Olympics in Sydney increased physical activity in adults) or more generally through empirical testing (Moss et al, 2019), narrowing the focus onto those areas predetermined in event planning. More attention needs to be given to how legacy (set out as ambitions and frameworks) can be realised (Bocarro et al, 2018; Thomson et al, 2018) or influenced by event planning and management (Kassens-Noor et al, 2015). The formulation of the HCV programme points to a need to explore how event management adapts in response to emerging evidence ahead of the event, especially where this suggests that event legacy ambitions might not be realised. In this respect, it underlines Rogerson's (2016) call for redefining the temporal framing of event legacy, offering further opportunity to explore how event leveraging and legacy can be inter-connected and legacy is a process as well as an outcome.

\section{References}

Allen, J. B., \& Bartle, M. (2014). Sport event volunteers' engagement: management matters. Managing Leisure, 19(1), 36-50.

Auld, C. (2008). Voluntary sport clubs: The potential for the development of social capital. In Nicholson, M and Hoye, R (eds) Sport and social capital (pp. 163-184). 
Routledge.

Auld, C., Cuskelly, G., \& Harrington, M. (2009). Managing volunteers to enhance the legacy potential of major events. People and Work in Events and Conventions: A research perspective, Oxfordshire: CABI, 181-192.

Bauman, A., Bellew, B., \& Craig, C. L. (2015). Did the 2000 Sydney Olympics increase physical activity among adult Australians?. Br J Sports Med, 49(4), 243-247.

Blackman, D., Benson, A. M., \& Dickson, T. J. (2017). Enabling event volunteer legacies: A knowledge management perspective. Event Management, 21(3), 233-250.

Blackshaw, T., \& Long, J. (2005). What's the big idea? A critical exploration of the concept of social capital and its incorporation into leisure policy discourse. Leisure studies, 24(3), 239-258.

Bocarro, J., Byers, T., \& Carter, C. (2018). Legacy of sporting and non-sporting mega event research. Legacies and mega-events: Facts or fairy tales, 7-24.

Bowling, A. (1997). Measuring health: A review of quality of life measurement scales. Buckingham: Open University Press.

Byers, T., Hayday, E., \& Pappous, A. S. (2019). A new conceptualization of mega sports event legacy delivery: Wicked problems and critical realist solution. Sport Management Review. (online)

Chalip, L. (2014). From legacy to leverage. In Leveraging legacies from sports megaevents: Concepts and cases (pp. 2-12). Palgrave Pivot, London.

Chalip, L. (2017). Event bidding, legacy, and leverage. The SAGE handbook of sport 
management, 401-420.

Coalter, F. (2007) A wider role for sport: Who's keeping the score? Oxford: Routledge Collins, M. F. (2003). Social exclusion from sport and leisure. In Houlihan, B (ed) Sport and society: A student introduction. London: Sage, p77-105

Cohen, D and Prusak, L (2001) In good company: how social capital makes organizations work, Harvard Business School Press, Boston MA

Cuskelly, G. (2008). Trends in sport volunteering and consequences for social capital. In: M. Nicholson and R. Hoye, eds. Sport and social capital. London: Elsevier Butterworth-Heinemann, 187-203.

Darcy, S., Dickson, T. J., \& Benson, A. M. (2014a). London 2012 Olympic and Paralympic Games: Including volunteers with disabilities-A podium performance?. Event Management, 18(4), 431-446.

Darcy, S., Maxwell, H., Edwards, M., Onyx, J., \& Sherker, S. (2014b). More than a sport and volunteer organisation: Investigating social capital development in a sporting organisation. Sport Management Review, 17(4), 395-406.

De Jong Gierveld, J., \& van Tilburg, T. (2006). A 6-item scale for overall, emotional, and social loneliness: Confirmatory tests on survey data. Research on Aging, 28, 582598.

Dickson, T., Darcy, S., Edwards, D. \& Terwiel, F. (2015) Sport mega-event volunteers' motivations and post-event intention to volunteer: The Sydney World Masters Games, 2009. Event Management, 19(2), 227-245

Doherty, A. (2009) The volunteer legacy of a major sport event. Journal of Policy 
Research in Tourism, Leisure and Events, 1(3), 185-207

Doherty, A., \& Misener, K. (2008). Community sport networks. In Nicholson, M and Hoye, R (eds) Sport and social capital (pp. 133-162). Routledge.

Downward, P., Lumsden, L. \& Ralston, R. (2005) 'Gender differences in sports event volunteering: insights from Crew 2002 at the XVII Commonwealth Games', Managing Leisure, 10 (4), 219-236

Dwyer, L., Mellor, R., Mistilis, N., \& Mules, T. (2000). A framework for assessing 'tangible' and 'intangible' impacts of events and conventions. Event management, 6(3), 175-189.

Farrell, J. M., Johnston, M. E., \& Twynam, G. D. (1998). Volunteer motivation, satisfaction, and management at an elite sporting competition. Journal of sport Management, 12(4), 288-300.

Gilster, M. E. (2012). Comparing neighborhood-focused activism and volunteerism: psychological well-being and social connectedness. Journal of Community Psychology, 40(7), 769-784.

Glasgow City Council (2009) Glasgow 2014 Legacy Framework. Glasgow: Glasgow City Council. Retrieved from https://www.glasgow.gov.uk/index. aspx?articleid=3249.

Glasgow Household Survey (2012), Ipsos Mor1, Glasgow. Accessed at https://www.glasgow.gov.uk/CHttpHandler.ashx?id=39554\&p=0

Glasgow Life (2013a) Briefing: Host City Glasgow project, Glasgow: Glasgow Life Glasgow Life (2013b) Host City Volunteers: fact sheet, Glasgow: Glasgow Life, 

Harris, M. (2012). London's Olympic Ambassadors: a legacy for public policy implementation?. Voluntary Sector Review, 3(3), 417-424.

Holmes, K., (2009). Volunteering, citizenship, and social capital: a review of UK government policy. Journal of policy research in tourism, leisure and events, 1, 265269.

Hoye, R., \& Nicholson, M. (2012). Life at the track: Country race clubs and social capital. International Review for the Sociology of Sport, 47(4), 461-474.

Hoye, R., Nicholson, M., \& Brown, K. (2015). Involvement in sport and social connectedness. International Review for the Sociology of Sport, 50(1), 3-21.

Hughes, M. E., Waite, L., Hawkley, L., \& Cacioppo, J. T. (2004). A short scale for measuring loneliness in large surveys: Results from two population-based studies. Research on Aging, 26(6), 655-672.

Kassens-Noor, E., Wilson, M., Müller, S., Maharaj, B., \& Huntoon, L. (2015). Towards a mega-event legacy framework. Leisure Studies, 34(6), 665-671.

Kawachi, I., \& Berkman, L. F. (2001). Social ties and mental health. Journal of Urban Health: The Bulletin of the New York Academy of Medicine, 78, 458-467.

Kay, T. \& Bradbury, S. (2009) Youth sport volunteering: developing social capital? Sport, education and society, 14, 121-140.

Kodama, E., Doherty, A., \& Popovic, M. (2013). Front line insight: an autoethnography of the Vancouver 2010 volunteer experience. European Sport Management Quarterly, 13(1), 76-93. 
Koutrou, N., Pappous, A., \& Johnson, A. (2016). Post-Event Volunteering Legacy: Did the London 2012 Games Induce a Sustainable Volunteer Engagement?. Sustainability, $8(12), 1221$

Lee, R. M., \& Robbins, S. B. (1995). Measuring belongingness: The social connectedness and the social assurance scales. Journal of counseling psychology, 42(2), 232.

Long, J., Welch, M., Bramham, P., Hylton, K., Butterfield, J. and Lloyd, E., 2002.

Count me in: The dimensions of social inclusion through culture and sport. Department for Culture, Media and Sport, London

Misener, L., \& Mason, D. S. (2006). Creating community networks: Can sporting events offer meaningful sources of social capital?. Managing Leisure, 11(1), 39-56.

Morgan, H. (2013). Sport volunteering, active citizenship and social capital enhancement: what role in the 'Big Society'?. International journal of sport policy and politics, 5(3), 381-395.

Moss, S. E., Gruben, K. H., \& Moss, J. (2019). An empirical test of the Olympic tourism legacy. Journal of Policy Research in Tourism, Leisure and Events, 11(1), 1634.

Nichols, G (2012) Volunteering for the Games. In V. Griginov (ed) Handbook of the London 2012 Olympic and Paralympic Games, Volume One: making the Games. London: Routledge, pp215-224

Nichols, G., \& Ralston, R. (2012). Lessons from the volunteering legacy of the 2002 Commonwealth Games. Urban Studies, 49(1), 169-184. 
Nichols, G and Ralston, R (2014) Volunteering for the Games. In V. Griginov (ed)

Handbook of the London 2012 Olympic and Paralympic Games, Volume 2: Celebrating the Games. London: Routledge, pp53-70

Nichols, G., \& Ralston, R. (2015). The legacy costs of delivering the 2012 Olympic and Paralympic Games through regulatory capitalism. Leisure Studies, 34(4), 389-404.

Preuss, H. (2015). A framework for identifying the legacies of a mega sport event. Leisure studies, 34(6), 643-664.

Rogerson, R. J. (2016). Re-defining temporal notions of event legacy: lessons from Glasgow's Commonwealth Games. Annals of leisure research, 19(4), 497-518.

Rogerson, R., Pavoni, A. \& Duncan, T. (2015) Participating as a Host City Volunteer: perspectives from those involved in the Glasgow 2014 Commonwealth Games.

Retrieved athttps://prodglportalv2.azureedge.net/media/2417/glasgow-2014participating-as-a-host-city-volunteer-2015.pdf

Rogerson, R., Reid, F., Sly, B. \& Nicholson, R. (2018) Three years on - the impact of being a Host City Volunteer at the 2014 Commonwealth Games. Retrieved at https://prodglportalv2.azureedge.net/media/2419/hcv-legacy-2018.pdf

Rogerson, R; Reid, F and Nicholson, R (forthcoming) The 2014 Host City Volunteers and event volunteering legacy, Event Management,

Russell, D., Peplau, L. A., \& Cutrona, C. E. (1980). The revised UCLA loneliness scale: Concurrent and discriminant validity evidence. Journal of Personality and Social Psychology, 28, 361-379.

Sly, B. (2018). Developing an Events Legacy. Presentation at the Sports Volunteering 
Research Network, October 2018.

SMG (2016) 'Taking volunteering to the people': an evaluation of the Host City

Volunteers (HCV) progamme, Social Marketing Gateway; Glasgow (for Glasgow Life)

Sport England, (2017) 'Volunteering in an active nation: Strategy 2017-2021' London:

Sport England

Thomson, A., Cuskelly, G., Toohey, K., Kennelly, M., Burton, P., \& Fredline, L.

(2018). Sport event legacy: A systematic quantitative review of literature. Sport

Management Review. 22(3), 295-321

Thomson, A., Schlenker, K., \& Schulenkorf, N. (2013). Conceptualizing sport event legacy. Event Management, 17(2), 111-122.

Timpone, R. J. (1998). Ties that bind: Measurement, demographics, and social connectedness. Political Behavior, 20(1), 53-77.

Tonts, M. (2005). Competitive sport and social capital in rural Australia. Journal of rural studies, 21(2), 137-149.

Wallstam, M., Ioannides, D., \& Pettersson, R. (2018). Evaluating the social impacts of events: in search of unified indicators for effective policymaking. Journal of Policy Research in Tourism, Leisure and Events, 1-20.

Welty Peachey, J., Cohen, A., Borland, J., \& Lyras, A. (2013). Building social capital: Examining the impact of Street Soccer USA on its volunteers. International Review for the Sociology of Sport, 48(1), 20-37.

Woodall, J. R., South, J., Southby, K., Kinsella, K., May, E., Bagnall, A., \& Coan, S. 
(2016). Exploring the experiences and impacts of volunteer applicants for the Glasgow 2014 Commonwealth Games.

Zakus, D., Skinner, J., \& Edwards, A. (2009). Social capital in Australian sport. Sport in society, 12(7), 986-998.

Zhuang, J., \& Girginov, V. (2012). Volunteer selection and social, human and political capital: a case study of the Beijing 2008 Olympic Games. Managing Leisure, 17(2-3), 239-256. 
Table 1: Feelings of social connectedness amongst the Host City Volunteers

\begin{tabular}{|l|l|l|l|l|l|}
\hline \% respondents & More & Same & Less & $\begin{array}{l}\text { Don't } \\
\text { know }\end{array}$ & Blank \\
\hline Talk to your neighbours & 14 & 68 & 4 & 3 & 11 \\
\hline $\begin{array}{l}\text { Meet up with other people } \\
\text { able now to influence } \\
\text { decisions affecting your } \\
\text { local area }\end{array}$ & 22 & 57 & 7 & 3 & 11 \\
\hline $\begin{array}{l}\text { feel more connected to } \\
\text { your local community }\end{array}$ & 19 & 49 & 7 & 13 & 12 \\
\hline
\end{tabular}


Table 2 - Involvement with social groups or clubs amongst Host City Volunteers.

(a) Changes in involvement

\begin{tabular}{|l|l|l|l|}
\hline & \multicolumn{2}{|l|}{ Involvement in last 12 months } & \\
\hline $\begin{array}{l}\text { Involvement prior } \\
\text { to 2014 Games }\end{array}$ & Yes & No & Total \\
\hline Yes & 165 & 34 & $\mathbf{1 9 9}$ \\
\hline No & 35 & 72 & $\mathbf{1 0 7}$ \\
\hline Don't' know & 9 & 9 & $\mathbf{1 8}$ \\
\hline
\end{tabular}

(b) Changes in frequency of involvement

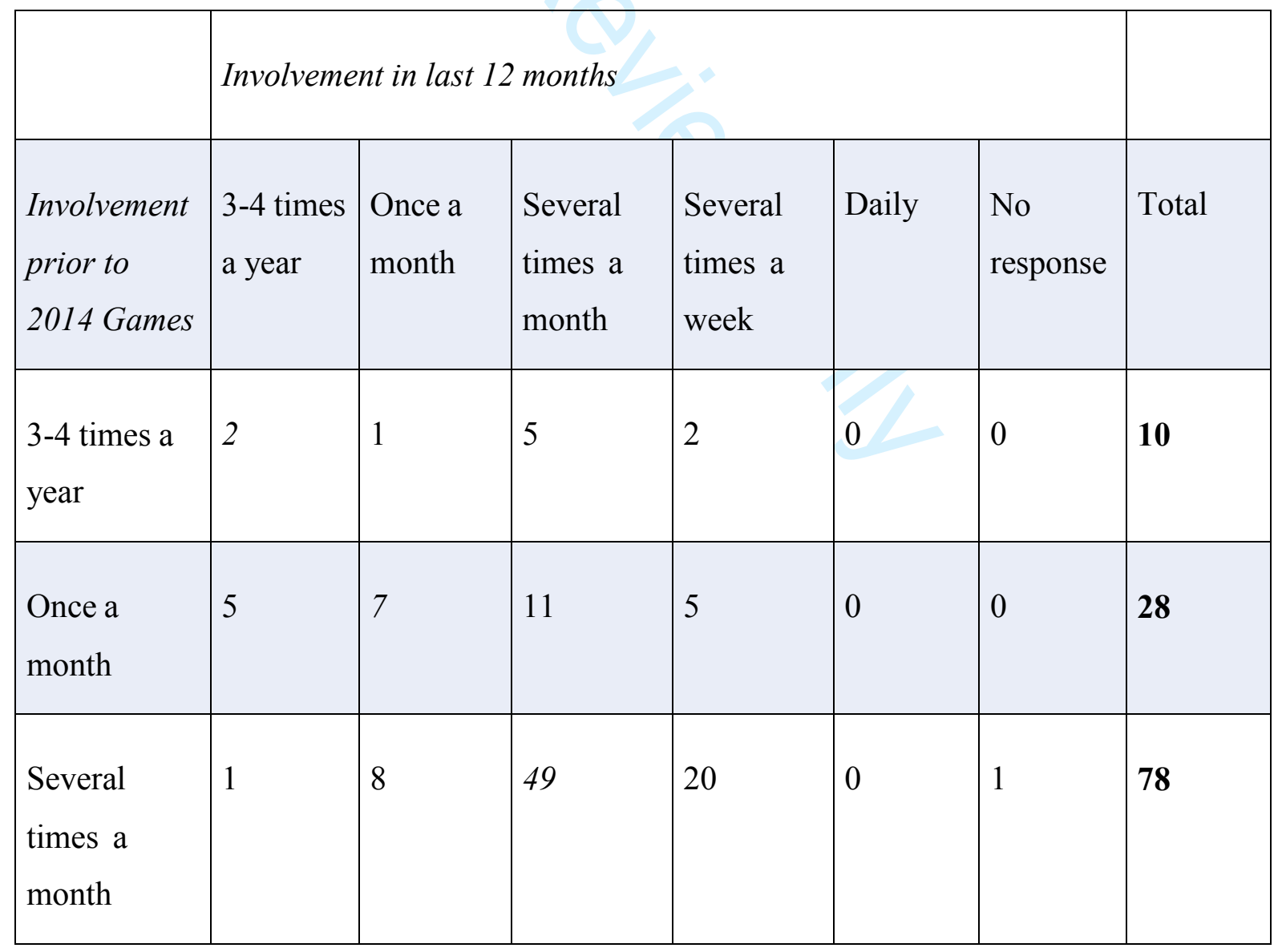




\begin{tabular}{|l|l|l|l|l|l|l|l|}
\hline $\begin{array}{l}\text { Several } \\
\text { times a } \\
\text { week }\end{array}$ & 4 & 14 & 0 & 25 & 1 & 1 & $\mathbf{4 5}$ \\
\hline Daily & 0 & 0 & 0 & 2 & 0 & 1 & $\mathbf{3}$ \\
\hline & $\mathbf{1 2}$ & $\mathbf{2 9}$ & $\mathbf{6 5}$ & $\mathbf{5 4}$ & $\mathbf{1}$ & $\mathbf{3}$ & $\mathbf{1 6 5}$ \\
\hline
\end{tabular}

Note: based on those in Table 2(a) who continued to have involvement over time. 